\title{
3D analysis at implant sites after soft tissue augmentation with two types of collagen matrices: a pilot study
}

\author{
Leonardo Mancini, Adriano Fratini, Francesco Tarallo, Lorenzo Maria Americo, Enrico Marchetti \\ Department of Life, Health and Environmental Sciences, University of L'Aquila, L'Aquila 67100 Coppito, Italy.
}

Correspondence to: Dr. Leonardo Mancini, Department of Life, Health and Environmental Sciences, University of L'Aquila, Piazza Salvatore Tommasi 1, L'Aquila 67100 Coppito, Italy. E-mail: leonardo.mancini@graduate.univaq.it

How to cite this article: Mancini L, Fratini A, Tarallo F, Americo LM, Marchetti E. 3D analysis at implant sites after soft tissue augmentation with two types of collagen matrices: a pilot study. Plast Aesthet Res 2021;8:26. https://dx.doi.org/10.20517/23479264.2021 .25

Received: 22 Mar 2021 First Decision: 13 Apr 2021 Revised: 13 Apr 2021 Accepted: 19 Apr 2021 Published: 17 May 2021

Academic Editors: Raúl González-García, Mario Aimetti Copy Editor: Xi-Jun Chen Production Editor: Xi-Jun Chen

\begin{abstract}
Soft tissue augmentation at the implant site is one of several techniques suggested in the case of soft and hard tissue deficiency after implant rehabilitation. The gold standard in this procedure is connective tissue graft (CTG), which is considered an autologous material with a high proliferative pattern. Today, several collagen matrices (VCMXs) are on the market as CTG substitutes and are recommended for this type of procedure. The aim of this case report is to compare the resorption process and the volume gain of two potential collagen matrices (VCMXA and $\mathrm{VCMXB}$ ) of porcine origin for soft tissue augmentation around single implants. 3D analysis with dedicated software (GOM inspect ${ }^{\circledR}$ Braunschweig, Germany) was performed to understand the volumetric and surface changes on the vestibular aspect and the amount of resorbed biomaterial at 7 days from the surgery and at 3 months of follow up. Considering the limitation of the four included patients and the different surgical sites (13 and 17 for VCMXA and 26 and 25 for VCMXB), both VCMXs showed interesting results with respect to the baseline at 7 days (VCMXA gain, $+2.93 \pm 1.65 \mathrm{~mm}$; VCMXB, $+2.58 \pm 1.11 \mathrm{~mm}$ ); however, after 3 months of follow up, an important remodelling process was present in both treated sites $(V C M X A,+2.00 \pm 0.99 \mathrm{~mm}$; VCMXB, $0.41 \pm$ $0.73 \mathrm{~mm}$ ). Soft tissue augmentation at the implant site resulted in a similar increase in volume for both the matrices. On the other hand, VCMXA seemed to preserve more volume at 3 months. Future randomised clinical trials are needed to confirm these results.
\end{abstract}


Keywords: Collagen-based matrix, dental implant, soft tissue augmentation, soft tissue volume, aesthetic outcome, keratinised tissue, peri-implant soft tissue

\section{INTRODUCTION}

Tooth replacement by means of dental implants is considered to be a predictable procedure in modern dentistry ${ }^{[1]}$. A key factor in predictably achieving good aesthetic and functional results in anterior restorations is to preserve or regain adequate tissue volume at the implant level ${ }^{[2]}$. From the point of view of soft tissues, several surgical techniques have been proposed to correct localised alveolar defects ${ }^{[3,4]}$. In fact, it has been widely demonstrated that soft tissue quality and quantity appear to play a crucial role in maintaining peri-implant health, stability and aesthetics over time ${ }^{[5,6]}$. In the case of volume deficiencies on the buccal side of dental implants, soft tissue augmentation surgery has been considered an integral part of implant therapy ${ }^{[7]}$. Various techniques and materials have been described in the literature to augment soft tissue volume, with autogenous subepithelial connective tissue graft being considered the gold standard $\mathrm{d}^{[7,8]}$.

However, several disadvantages related to the use of autogenous soft tissue graft have been described including an increase in patient morbidity due to the graft harvesting and some inter-individual variations in terms of availability and quality at the donor site, which further increase the burden on the patient ${ }^{[0,10]}$. To overcome these disadvantages, substitutes for soft tissue grafts as collagen matrix (VCMXs) were developed. Numerous preclinical and clinical studies evaluated its three-dimensional stability demonstrating promising short-term results ${ }^{[11]}$. Furthermore, this collagen matrix (VCMXA) resulted in an increase in soft tissue volume at implant sites that were non-inferior to an autogenous connective tissue graft (CTG) in two randomised clinical trials ${ }^{[12,13]}$. With the same goals, another type of connective substitute has been developed: this innovative regeneration material, based on the same glymatrix, is a biodegradable and biocompatible collagen membrane (VCMXB). The collagen is extracted from porcine tendons in an approved, controlled, standardised procedure ${ }^{[14]}$. This material has resulted in a favourable and stable clinical outcome for lateral augmentation of a deficient ridge ${ }^{[15,16]}$.

The aim of this clinical pilot study was to compare the resorption process and the surface alteration at 7 days and 3 months of follow up for two types of VCMXs in soft tissue augmentation at implant sites.

\section{CASE REPORT}

This case report was assessed according to the C.A.R.E. case report guidelines ${ }^{[17]}$. After receiving a full description of the periodontal surgical procedure, all patients signed informed consent in full accordance with the Guidelines of the Helsinki World Medical Association Declaration and the revision of the 2013 Good Clinical Practice Guides. Moreover, the study was performed in compliance with the ethical standards in the field and the norms established by the Internal Review Board of the University of L'Aquila (D.R. n. 206/2013).

\section{Patient information}

Four consecutive non-smoking patients (mean age of $51 \pm 9.8$ years) reporting a missing tooth in the upper maxilla were enrolled. Table 1 describes the age, sex and surgical site for each patient. During the first visit, an extraoral and intraoral examination was performed to assess the presence of possible alterations and diseases. All four patients were healthy and not systemically compromised. Each patient was informed about the possibility of choosing either CTG or VCMX in order to set patient preferences. Collagen matrices were the first choice for all candidates, which prevented a second surgical site and resulted in less morbidity during the healing phase. 
Table 1. Characteristics of the enrolled patients

\begin{tabular}{lllllll}
\hline Patient & Age (years) & Sex & Surgical site & Smoking & Collagen matrix & Drugs \\
\hline A & 60 & M & 13 & No & VCMXA & Statin, cardio aspirin \\
B & 49 & F & 17 & No & VCMXA & No \\
C & 57 & M & 26 & No & VCMXB & No \\
D & 38 & F & 25 & No & VCMXB & No \\
\hline
\end{tabular}

\section{Intraoral examination}

The intraoral examination revealed the presence of a missing tooth in each patient and the presence of an important deficit of soft/hard tissue on the buccal aspect due to the remodelling process of the alveolar socket. During the first visit, a periodontal screening was achieved, and normal probing depth and clinical attachment level were present in the mesial and distal teeth of the defect.

\section{Presurgical considerations}

After signing the informed consent, patients underwent a first impression with polyether (Impregum Penta, $3 \mathrm{M} \mathrm{ESPE}^{\oplus}$; St. Paul, MN, United States) in order to collect data regarding the baseline parameters of the soft tissue surface and volume.

\section{Surgical procedures}

All surgical procedures followed standard principles and were performed by an experienced clinician. Intraoral antisepsis was performed with $0.20 \%$ chlorhexidine rinse for $1 \mathrm{~min}$. Local anaesthesia (Citocartin ${ }^{\circ}$ confirm with adrenalina $40 \mathrm{mg} / \mathrm{mL}+10 \mathrm{mcg} / \mathrm{mL}$, Molteni Dental Srl, Milan, Italy) on the buccal and palatal/lingual aspects was performed. A surgical approach for implant positioning was carried out with an in crestal incision in the edentulous area followed by an intrasulcular incision on the adjacent teeth. This procedure allowed for better coverage and stabilisation of the gingival flap. Full-thickness flaps were realised using a scalpel with blade No. 15c (Swann Morton, Sheffield, England). The elevation of the flap was performed in the most atraumatic way possible, leaving interdental tissues intact. In addition, the flaps were extended more apically on the buccal bone plate to ensure that the barrier at placement rested on the bone along its entire extension. After the full split detachment, no bone corrections were performed in any case. The procedure for the implant placement was carried out according to the manufacturer's indications (Root-line, Camlog Biotechnologies AG, Basel, Switzerland); the length and diameter of the implant were previously chosen during treatment planning. Transmucosal implants were inserted. Prior to insertion, the VCMXA (Fibro-Gide ${ }^{\circledR}$, Geistlich, Wolhusen, Switzerland; or VCMXB Ossix ${ }^{\circledR}$ Volumax, Datum dental, Lod, Israel) was shaped and reduced in order to reach a suitable dimension, but the thickness was maintained [Figure 1]. The flap, at this point, was relocated in the original position. Then, 5.0 tension-free sutures (Resorb $^{\circ}$ and Monosoft ${ }^{\circ}$, Sweden \& Martina S.p.A., Padova, Italia) were used with the intention of achieving primary closure. A horizontal internal mattress suture was used to anchor and stabilise the graft on the buccal flap. Single O sutures were applied on the other incisions. Antibiotics (amoxicillin + clavulanic acid $875 \mathrm{mg} / 125 \mathrm{mg}$ ) were administered starting on the morning before surgery and extending for 6 days.

\section{Postoperative intervention}

Every patient was asked to avoid any form of brushing in the operated area and to rinse with chlorhexidine $0.12 \%$ for $1 \mathrm{~min}$ three times per day. The rinsing procedure started the next evening after surgery due to the cytotoxic effect of the chlorhexidine against keratocytes, which has been previously proven ${ }^{[18,19]}$. These instructions were followed for 2 weeks. Painkiller use (paracetamol $500 \mathrm{mg}$ or naproxen $500 \mathrm{mg}$ ) was advised when necessary, and the patient was requested to report the consumption of the medication. Sutures were removed after 7 days, and a second impression was achieved. At 3 months, all patients 

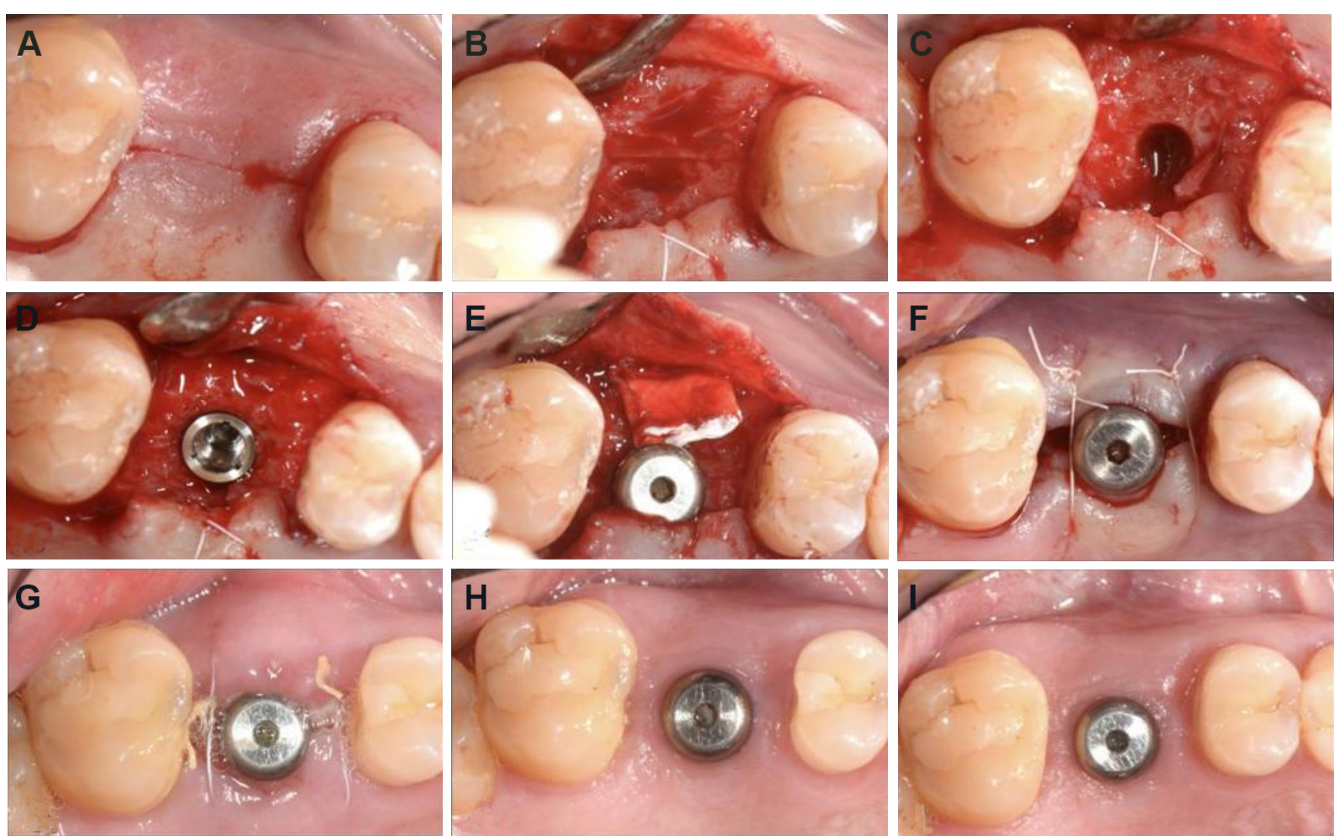

Figure 1. (A) Incision line; (B) full thickness flap; (C) implant site preparation; (D) implant positioning; (E) VCMX allocation on the buccal aspect; (F) O sutures and horizontal mattress; and resulting primary intention healing $(\mathrm{G})$ at 7 days from the surgery and $(\mathrm{H}, \mathrm{I}) 3$ months of follow up.

underwent a third dental impression for the assessment of VCMX remodelling.

\section{Main study parameter/endpoint}

Thickness stability of the soft tissue at the buccal aspect of the implant site was the principal aim. It was reported at the baseline, at suture removal (7 days) and after 3 months of follow up [Figure 2]. The aesthetic outcome was evaluated to understand the patient's perception [Table 2].

\section{Three-dimensional analysis}

All the dental impressions were transformed in master cast with a dental stone type III (Fujirock, GC), optically scanned with a 3D scanner (Dental Wings 7th series) and digitised to collect stereolithography (STL) files. A novel and sophisticated program (GOM inspect ${ }^{\bullet}$, Braunschweig, Germany) was used for the superimposition of the STL files to evaluate volumetrics and surface alternation between baseline and postop at 7 days and between baseline and follow up at 3 months, and the discrepancy between postop at 7 days and 3 months was determined to understand the resorption time for each matrix [Figure 3].

The 3D evaluation revealed results at 7 days from the surgery for the VCMXs. At 3 months, the resorption was evident in the superimposed images. The data show remodelling of the VCMXs for both types. Table 3 depicts the data regarding surface alteration for each patient expressed in millimetres and patients' aesthetic evaluation.

Volumetric changes were evident in all treated areas, with a volume reduction at 3 months compared to the baseline and a reduction of almost 50\% from the postop to the 3 months follow up, as reported in Table 4 . For each type of analysis, a superposition was obtained to have a visual inspection of the differences [ Figures 4 and 5]. 
Table 2. Scale used for patient aesthetic evaluation

\begin{tabular}{lllll}
\hline Very unsatisfied & Unsatisfied & Neutral & Satisfied & Very satisfied \\
\hline 1 & 2 & 3 & 4 & 5 \\
\hline
\end{tabular}

Table 3. Surface changes and patient aesthetic evaluation

\begin{tabular}{|c|c|c|c|c|c|c|}
\hline Patient & $\begin{array}{l}\text { Discrepancy between } \\
\text { the surface at } \\
\text { baseline and post-op }\end{array}$ & $\begin{array}{l}\text { Discrepancy between } \\
\text { the surface at } \\
\text { baseline and } 3 \\
\text { months }\end{array}$ & $\begin{array}{l}\text { Discrepancy between } \\
\text { the surface at post- } \\
\text { op and } 3 \text { months }\end{array}$ & $\begin{array}{l}\text { Aesthetic } \\
\text { evaluation } \\
\text { baseline }\end{array}$ & $\begin{array}{l}\text { Aesthetic } \\
\text { evaluation } \\
\text { post-op }\end{array}$ & $\begin{array}{l}\text { Aesthetic } \\
\text { evaluation at } 3 \\
\text { months }\end{array}$ \\
\hline A & $2.93 \pm 1.65 \mathrm{~mm}$ & $2.00 \pm 0.99 \mathrm{~mm}$ & $-0.93 \pm 1.02 \mathrm{~mm}$ & 2 & 2 & 5 \\
\hline B & $2.53 \pm 1.42 \mathrm{~mm}$ & $1.94 \pm 0.84 \mathrm{~mm}$ & $-0.59 \pm 1.15 \mathrm{~mm}$ & 1 & 3 & 4 \\
\hline C & $1.90 \pm 0.57 \mathrm{~mm}$ & $0.28 \pm 0.91 \mathrm{~mm}$ & $-1.62 \pm 0.39 \mathrm{~mm}$ & 1 & 4 & 2 \\
\hline D & $2.58 \pm 1.11 \mathrm{~mm}$ & $0.41 \pm 0.73 \mathrm{~mm}$ & $-2.17 \pm 0.61 \mathrm{~mm}$ & 2 & 5 & 4 \\
\hline
\end{tabular}

Table 4. Volumetric changes in $\mathrm{mm}^{3}$ for each site

\begin{tabular}{|c|c|c|c|c|}
\hline Patient & $\begin{array}{l}\text { Volume alteration between } \\
\text { baseline and post-op }\end{array}$ & $\begin{array}{l}\text { Volume alteration between } \\
\text { baseline and } 3 \text { months }\end{array}$ & $\begin{array}{l}\text { Volume alteration between post- } \\
\text { op and } 3 \text { months }\end{array}$ & $\begin{array}{l}\text { Type of } \\
\text { matrix }\end{array}$ \\
\hline A & $+108 \mathrm{~mm}^{3}$ & $+85 \mathrm{~mm}^{3}$ & $-185 \mathrm{~mm}^{3}$ & VCMXA \\
\hline B & $+203 \mathrm{~mm}^{3}$ & $+65 \mathrm{~mm}^{3}$ & $-138 \mathrm{~mm}^{3}$ & VCMXA \\
\hline C & $+242 \mathrm{~mm}^{3}$ & $+25 \mathrm{~mm}^{3}$ & $-168 \mathrm{~mm}^{3}$ & VCMXB \\
\hline D & $+298 \mathrm{~mm}^{3}$ & $+41 \mathrm{~mm}^{3}$ & $-100 \mathrm{~mm}^{3}$ & VCMXB \\
\hline
\end{tabular}
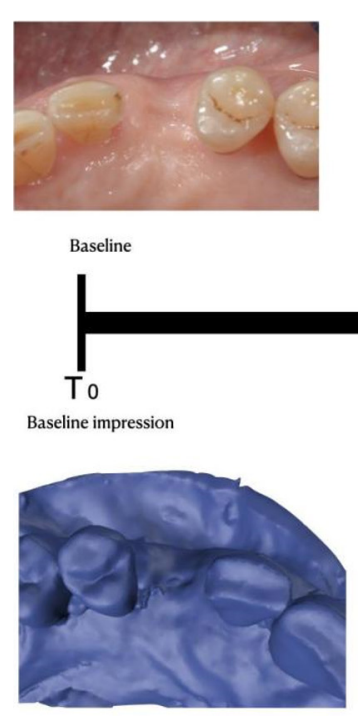

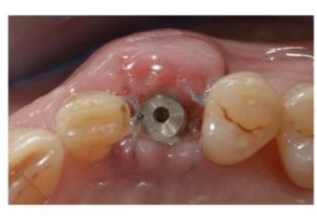

Suture removal

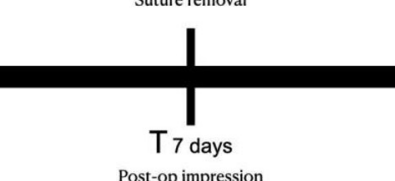

Post-op impression

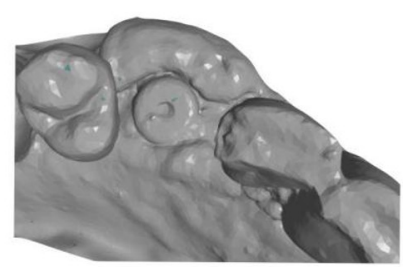

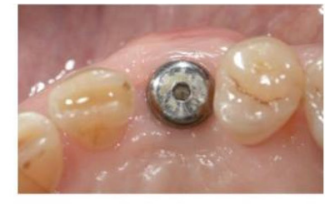

Follow up
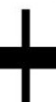

T 3 months

Follow-up impression

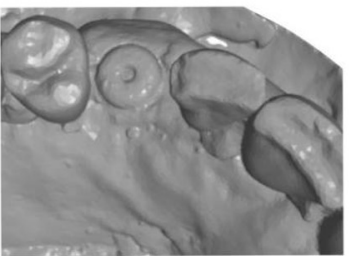

Figure 2. Representation of the workflow for the analysis of soft tissue alteration.

A visual inspection was achieved to understand the possible type of resorption of each matrix and the biological principles around the healing phase. The resorption process seems to start from the centre of the matrix for VCMXB and from the edges for VCMXA. This result is evident through the analysis of the superimposition of postop and 3 months follow up, as reported in Figure 6. Moreover, according to this 3D evaluation, the resorption process starts form the mucogingival margin to the most coronal part of the soft tissue. 


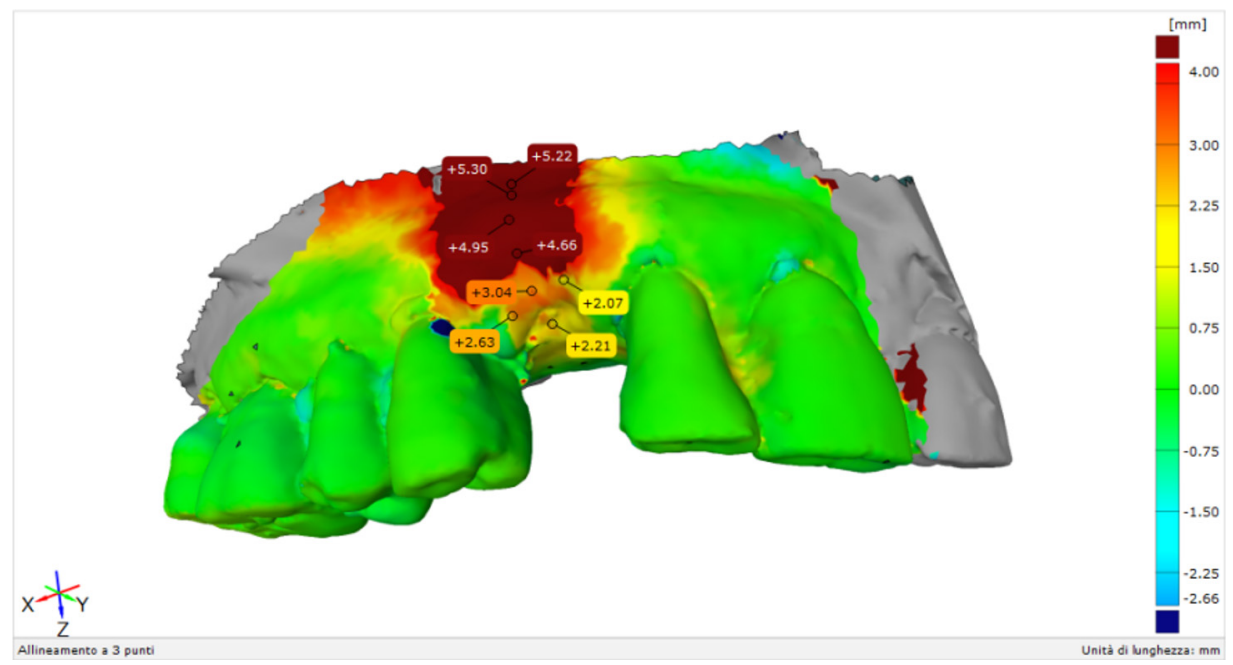

Figure 3. Representation of the superimposing process to analyse the surface discrepancy in millimetres with respect to the baseline.
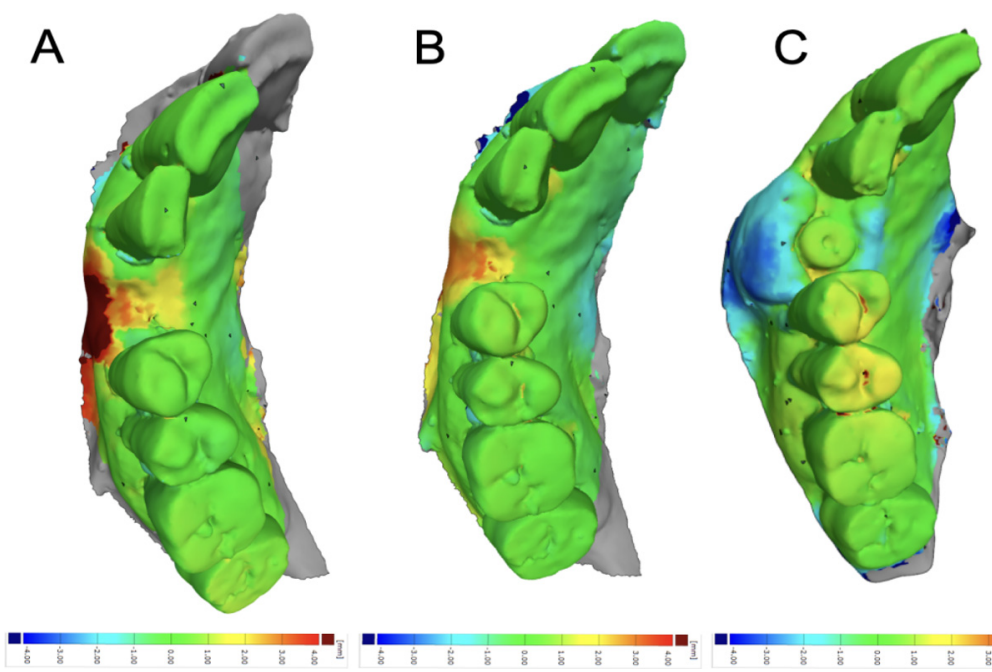

Figure 4. Patient $A / V C M X A$ surface matching: (A) baseline-postop; (B) baseline-three months; and (C) postop-three months.

\section{DISCUSSION}

In the cases of soft tissue deficiency on the buccal aspect of dental implants, soft tissue augmentation techniques have become an integral part of implant therapy ${ }^{[7]}$. According to a recent systematic review, soft tissue augmentation is a reliable technique to improve soft tissue phenotype and keratinised width ${ }^{[20]}$. Moreover, mucosal biotype and aesthetic expectations are the main factors that lead to the necessity of soft tissue augmentation; according to two recent systematic reviews, implant sites and partially edentulous patients obtained some advantages in soft tissue volume increase since autogenous CTGs are considered the gold standard in soft tissue augmentation ${ }^{[7,20]}$. However, the morbidity associated with graft harvesting and the risk of intra- and post-operative complications such as bleeding, infection or necrosis also need to be considered $^{[21,22]}$. To reduce the complications due to harvesting procedures, research activities have focused on the development of soft tissue substitutes of various origin ${ }^{[23]}$. An eligible material needs to fulfil two main criteria: assure the space-maintenance over time and provide favourable mechanical and biological properties during the remodelling processes ${ }^{[24]}$. Recently, a new collagen matrix offers mechanical stability 

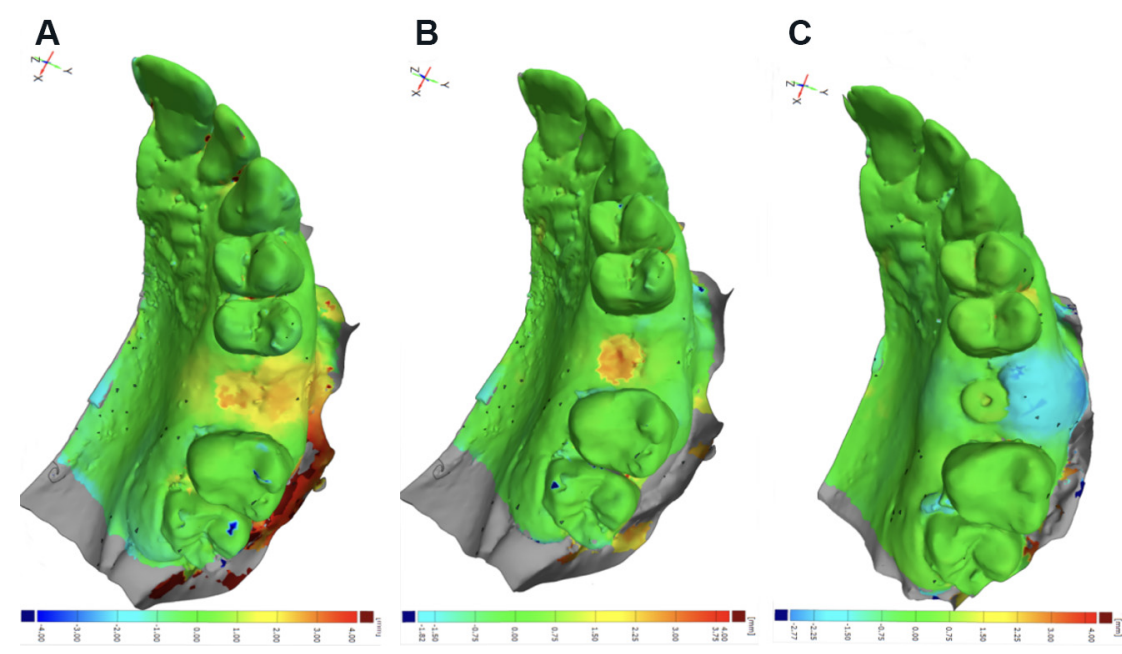

Figure 5. Patient C/VCMXB surface matching: (A) baseline-postop; (B) baseline-three months; and (C) postop-three months.

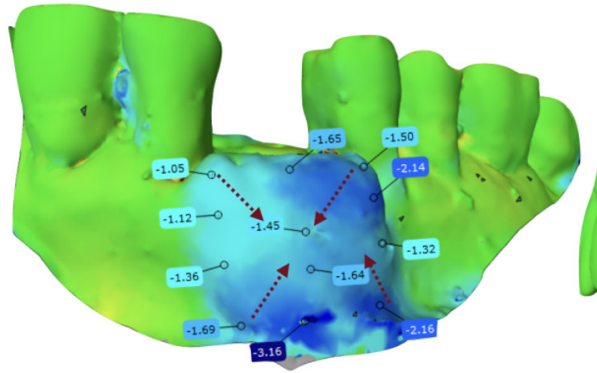

VCMXA

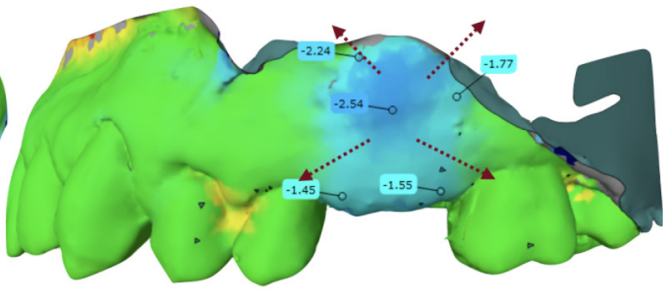

VCMXB

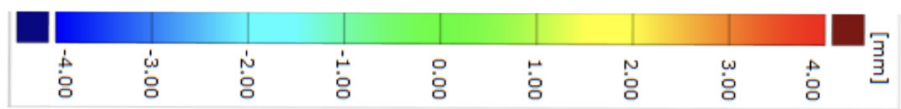

Figure 6. Resorption pattern for VCMXA and VCMXB. The red arrows describe the resorption direction for each aspect.

associated with a good biological behaviour, which promoted tissue formation, angiogenesis and similar outcomes compared to the gold standard in terms of volume increases in a pre-clinical model ${ }^{[25,26]}$. For the same purposes, a material comprised of a biodegradable and biocompatible crosslinked collagen scaffold was developed. In a case report, the Ossix ${ }^{\odot}$ Volumax collagen scaffold restored the deficient volume and resulted in an anatomically correct emergence profile ${ }^{[14]}$. Because of its expansion qualities, this material may serve as a substitute for connective tissue harvested from a donor site, simplifying the surgical procedure and simultaneously reducing morbidity. The present pilot study aimed to understand and investigate the resorption process and the vestibular remodelling of the soft tissue for two types of collagen matrices with a $3 \mathrm{D}$ superimposition program. According to the literature, VCMXs are reliable biomaterials in soft tissue augmentation around implants, with comparable results to the CTG. Our analysis showed almost equal results for both VCMX types. However, VCMXA seems to have a slow resorption process. This condition is probably due to the thickness of almost $6 \mathrm{~mm}$ and the crosslinking process. As opposed to VCMXA, VCMXB showed fewer promising results due to its thickness, as a double layer, of $4 \mathrm{~mm}$ and due to the glycation process, which is used for making collagen more resistant and biocompatible. Moreover, this type of matrix was first developed for guided bone regeneration and guided tissue regeneration. Today, 
it is also suggested in soft tissue augmentation. After comparing our results with previous randomised clinical trials, our data seem to be in line with the studies by Thoma et al. ${ }^{[12]}$ and Zeltner et al. ${ }^{[13]}$ regarding the buccal gain of VCMXA $(0.77 \pm 0.74 \mathrm{~mm} ; 1.1 \pm 1.4 \mathrm{~mm})^{[1,12]}$. Unfortunately, regarding VCMXB, there are no data regarding these types of $3 \mathrm{D}$ evaluations. The restricted number of cases, the possible bias due to the use of analogic models, the different surgical sites and the short follow up might be limitations that affect the final evaluation. However, according to a recent systematic review by Tavelli et al. ${ }^{[20]}$, in the $3 \mathrm{D}$ analysis workflow for soft tissue evaluation, the use of master cast should not be considered a limitation if the casts are all made with the same products. Furthermore, through the $3 \mathrm{D}$ program, it is possible to exclude the presence of artefacts from the STL files, preventing alterations ${ }^{[27]}$. Interestingly, the patient aesthetic evaluation positively judged VCMXA but was neutral for VCMXB. The evaluation was carried out before the prosthetic rehabilitation. In conclusion, for a short follow-up time, VCMXA seems to maintain the volume and surface better than VCMXB. However, both matrices improved the soft tissue thickness on the buccal aspect.

\section{DECLARATIONS}

\section{Authors' contributions}

To the conception and design of the study, performed data analysis and interpretation, performed data acquisition, and provided administrative, technical, and material support: Mancini L, Fratini A, Tarallo F, Americo LM, Marchetti E

\section{Availability of data and materials}

Not applicable.

\section{Financial support and sponsorship}

None.

\section{Conflicts of interest}

All authors declare that there are no conflicts of interest.

\section{Ethical approval and consent to participate}

This case report was assessed according to the C.A.R.E. case report guidelines. All patients signed informed consent in full accordance with the Guidelines of the Helsinki World Medical Association Declaration and the revision of the 2013 Good Clinical Practice Guides. Moreover, in compliance with the ethical standards in the field and the norms established by the Internal Review Board of the University of L'Aquila (D.R. n. 206/2013).

\section{Consent for publication}

Not applicable.

\section{Copyright}

(c) The Author(s) 2021.

\section{REFERENCES}

1. Lekholm U, Gunne J, Henry P, et al. Survival of the Brånemark implant in partially edentulous jaws: a 10- year prospective multicenter study. Int J Oral Maxillofac Implants 1999;14:639-45. PubMed

2. Romandini M, Pedrinaci I, Lima C, Soldini MC, Araoz A, Sanz M. Prevalence and risk/protective indicators of buccal soft tissue dehiscence around dental implants. J Clin Periodontol 2021;48:455-63. DOI PubMed

3. Prato GP, Cairo F, Tinti C, Cortellini P, Muzzi L, Mancini EA. Prevention of alveolar ridge deformities and reconstruction of lost anatomy: a review of surgical approaches. Int J Periodontics Restorative Dent 2004;24:434-45. DOI PubMed

4. Avila-Ortiz G, Gubler M, Romero-Bustillos M, Nicholas CL, Zimmerman MB, Barwacz CA. Efficacy of alveolar ridge preservation: a randomized controlled trial. J Dent Res 2020;99:402-9. DOI PubMed 
5. Cairo F, Pagliaro U, Nieri M. Soft tissue management at implant sites. J Clin Periodontol 2008;35:163-7. DOI PubMed

6. Akcalı A, Trullenque-Eriksson A, Sun C, Petrie A, Nibali L, Donos N. What is the effect of soft tissue thickness on crestal bone loss around dental implants? Clin Oral Implants Res 2017;28:1046-53. DOI PubMed

7. Gobbato L, Avila-Ortiz G, Sohrabi K, Wang CW, Karimbux N. The effect of keratinized mucosa width on peri-implant health: a systematic review. Int J Oral Maxillofac Implants 2013;28:1536-45. DOI PubMed

8. Thoma DS, Mühlemann S, Jung RE. Critical soft-tissue dimensions with dental implants and treatment concepts. Periodontol 2000 2014;66:106-18. DOI PubMed

9. Bassetti RG, Stähli A, Bassetti MA, Sculean A. Soft tissue augmentation around osseointegrated and uncovered dental implants: a systematic review. Clin Oral Investig 2017;21:53-70. DOI PubMed

10. Benninger B, Andrews K, Carter W. Clinical measurements of hard palate and implications for subepithelial connective tissue grafts with suggestions for palatal nomenclature. J Oral Maxillofac Surg 2012;70:149-53. DOI PubMed

11. Burkhardt R, Hämmerle CH, Lang NP; Research Group on Oral Soft Tissue Biology \& Wound Healing. Self-reported pain perception of patients after mucosal graft harvesting in the palatal area. J Clin Periodontol 2015;42:281-7. DOI PubMed

12. Thoma DS, Zeltner M, Hilbe M, Hämmerle CH, Hüsler J, Jung RE. Randomized controlled clinical study evaluating effectiveness and safety of a volume-stable collagen matrix compared to autogenous connective tissue grafts for soft tissue augmentation at implant sites. J Clin Periodontol 2016;43:874-85. DOI PubMed

13. Zeltner M, Jung RE, Hämmerle CH, Hüsler J, Thoma DS. Randomized controlled clinical study comparing a volume-stable collagen matrix to autogenous connective tissue grafts for soft tissue augmentation at implant sites: linear volumetric soft tissue changes up to 3 months. J Clin Periodontol 2017;44:446-53. DOI PubMed

14. Huber S, Zeltner M, Hämmerle CHF, Jung RE, Thoma DS. Non-interventional 1-year follow-up study of peri-implant soft tissues following previous soft tissue augmentation and crown insertion in single-tooth gaps. J Clin Periodontol 2018;45:504-12. DOI PubMed

15. Smidt A, Gutmacher Z, Sharon E. A nouveau collagen scaffold to simplify lateral augmentation of deficient ridges between natural teeth. Quintessence Int 2019;50:576-82. DOI PubMed

16. Scheyer ET, McGuire MK. Evaluation of premature membrane exposure and early healing in guided bone regeneration of peri-implant dehiscence and fenestration defects with a slowly resorbing porcine collagen ribose cross-linked membrane: A consecutive case series. Clin Adv Periodontics 2015;5:165-70. DOI PubMed

17. Riley DS, Barber MS, Kienle GS, et al. CARE guidelines for case reports: explanation and elaboration document. J Clin Epidemiol 2017;89:218-35. DOI PubMed

18. John G, Becker J, Schwarz F. Effects of taurolidine and chlorhexidine on SaOS-2 cells and human gingival fibroblasts grown on implant surfaces. Int J Oral Maxillofac Implants 2014;29:728-34. DOI PubMed

19. Müller HD, Eick S, Moritz A, Lussi A, Gruber R. Cytotoxicity and antimicrobial activity of oral rinses in vitro. Biomed Res Int 2017;2017:4019723. DOI PubMed PMC

20. Tavelli L, Barootchi S, Avila-Ortiz G, Urban IA, Giannobile WV, Wang HL. Peri-implant soft tissue phenotype modification and its impact on peri-implant health: A systematic review and network meta-analysis. J Periodontol 2021;92:21-44. DOI PubMed

21. Thoma DS, Benić GI, Zwahlen M, Hämmerle CH, Jung RE. A systematic review assessing soft tissue augmentation techniques. Clin Oral Implants Res 2009;20 Suppl 4:146-65. DOI PubMed

22. Pizzo M, Modica F, Bethaz N, Priotto P, Romagnoli R. The connective tissue graft: a comparative clinical evaluation of wound healing at the palatal donor site. A preliminary study. J Clin Periodontol 2002;29:848-54. DOI PubMed

23. Soileau KM, Brannon RB. A histologic evaluation of various stages of palatal healing following subepithelial connective tissue grafting procedures: a comparison of eight cases. J Periodontol 2006;77:1267-73. DOI PubMed

24. Zuhr O, Bäumer D, Hürzeler M. The addition of soft tissue replacement grafts in plastic periodontal and implant surgery: critical elements in design and execution. J Clin Periodontol 2014;41 Suppl 15:S123-42. DOI PubMed

25. Mathes SH, Wohlwend L, Uebersax L, et al. A bioreactor test system to mimic the biological and mechanical environment of oral soft tissues and to evaluate substitutes for connective tissue grafts. Biotechnol Bioeng 2010;107:1029-39. DOI PubMed

26. Thoma DS, Villar CC, Cochran DL, Hämmerle CH, Jung RE. Tissue integration of collagen-based matrices: an experimental study in mice. Clin Oral Implants Res 2012;23:1333-9. DOI PubMed

27. Tavelli L, Barootchi S, Majzoub J, Siqueira R, Mendonça G, Wang HL. Volumetric changes at implant sites: A systematic appraisal of traditional methods and optical scanning-based digital technologies. J Clin Periodontol 2021;48:315-34. DOI PubMed 